\title{
Evaluation of infestation by cereal leaf beetles (Oulema spp.) on six varieties of durum wheat (Triticum dirum, Desf.) seedlings in arid conditions of Setif, Algeria
}

\author{
Rouag $^{1}$ N., A. Mekhlouf ${ }^{1}$ and M. Makhlouf ${ }^{2}$ \\ ${ }^{1}$ Department of Agronomy, University Ferhat ABBAS, Sétif 1 - Algeria \\ ${ }^{2}$ Technical Institute for Field Crops, Sétif - Algeria
}

\begin{abstract}
The abundance of cereal leaf beetle on six durum wheat varieties (Triticum durum Desf.) and the influence of leaf flags infestation on grain yield per spike were studied. The results show the existence of two species of beetle at the experimental site (ITGC, Sétif), namely Oulema melanopus and Oulema hoffmannseggi. The study shows also, that varieties tested were infested at different rates and there is a negative effect between the infestation rate of the flag leaf and grain weight per ear. Thus, the rate of loss of grain per spike ranged range from $3.48 \%$ in Boussellam variety to $23.15 \%$ in Megress variety if the infestation rate of the flag leaf is less than $10 \%$, then the rate of loss in grain per spike can vary between $29.35 \%$ in Boussellam to $85.71 \%$ in Ofanto if the infestation rate of flag leaf is greater than $40 \%$.
\end{abstract}

Keywords: Cereal leaf beetle, Oulema spp., durum, infestation.

\section{INTRODUCTION}

The beetle is an invasive insect pest of crops of small grains, especially oats, wheat and barley (Olfert et al., 2004). Oulema melanopus is the most important species distributed worldwide. It was met at the majority of cereals areas, Asia, Europe (Doug, 2010). It was detected also in North Africa, in Algeria (Bounechada, 1990) and at Tunisia and Morocco (Maican and Serafim, 2009). In crops of winter wheat yield losses can reach 25\% (Webster, 1977), 28-49\% for spring wheat (Kolarov, 1988, Webster et al., 1972) and barley $19-52 \%$ (Webster and Smith, 1979). Vitvitzky and Koval (1984) showed that the yield loss in wheat per year varies from 10 to $20 \%$. If the flag leaf is damaged $90 \%$, yield loss is about $23 \%$ (Gallun et al., 1967).

Most of the damage is caused by larvae feeding on leaf tissue, leaving long strips on the upper leaf surface while the bottom surface remains intact (Royce and Simko, 2000). Fields seem heavily damaged silver and larval density of 22-26 larvae per 100 stems of winter wheat may caused yield losses in the range of 0.5 to $4 \%$. (Ulrich et al., 2004)

In recent years, the cereal leaf beetle has been a remarkable development in the plots of the experimental station of the Institute of Technical Crops (ITGC, Sétif, Algeria). This prompted us to conduct a study of the populations dynamics of cereal leaf beetles and damage assessment on six durum wheat varieties by studying the relationship between infestation rate of the flag leaf and grain weight per spike.

\section{MATERIALS AND METHODS}

The study was conducted at the experimental farm of the ITGC, Sétif. This site is typical of semi-arid areas at an altitude of $980 \mathrm{~m}$ and geographical coordinates $36^{\circ} 08^{\prime} \mathrm{N}, 5^{\circ} 20^{\prime} \mathrm{E}$. The monitoring of cereal leaf beetles population dynamic was done through counting adult beetles individuals by adopting the method of hunting for, followed by the collection of some specimens which are preserved for later identification. The larvae are placed in boxes and fed with pieces of wheat leaves under ambient temperature, according to Chambon et al. (1983).

The estimation of beetle's abundance was obtained by random sampling. Monitoring was based on ratings made weekly at 10 plots with an area of $24 \mathrm{~m}^{2}$ each $(20 \mathrm{~m} \times 1.20 \mathrm{~m})$ grown by a variety of durum wheat. Four elementary plots with an area of $6 \mathrm{~m}^{2}$ $(5 \mathrm{~m} \times 1.20 \mathrm{~m})$ each, were taken as replicates for each variety. The stratified random sampling method was adopted according to (Gillet, 2000). The strata are represented by elementary plots devoted to estimating beetles abundance. The observations began on 14 April 2011 and ended on 20 June 2011, date of manual harvesting.

Determining the relationship between the infestation rate of leaf flags and grain weight per ear translates the damage caused by cereal leaf beetles. To this 
end, twelve meters of infested leaves strands flags were chosen to obtain four classes according to the degree of attack on each variety. Three leaves per class flags were chosen, representing three replications. A total of 120 meters strands in leaves attacked flags were selected in an intentional way, representing six wheat varieties. The meters strands are then photographed and the infection rate was assessed using image processing software (Pro Mesurim 08, Version 3.3). This gives us the percentage of leaf area damaged by cereal leaf beetles over the entire surface of the leaf flag. The meters strands are then grouped into 4 classes as showed in Figure1.

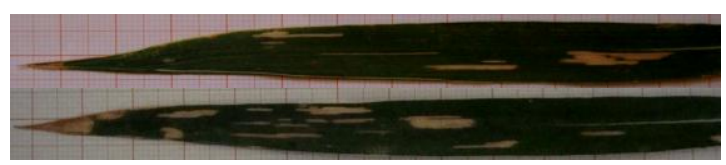

Class I: Attack on flag leaf less than $10 \%$

Class II: Attack of flag leaf between $10 \%$ and $20 \%$.

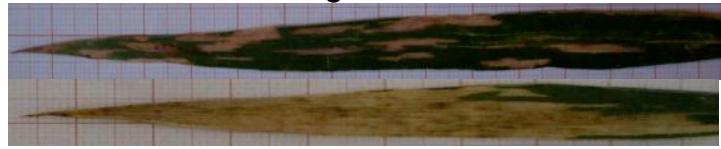

Class III: Attack on flag leaf between $20 \%$ and $40 \%$

Class IV: Attack on flag leaf more than $40 \%$.

\section{Fig. 1: Classification according to the infestation rate} of leaf flags.

The infection rate was evaluated through counting the number of plants infested per $\mathrm{m}^{2}$ of each variety. Three observations are made from May 25 to June 08 at an interval of 15 days. While grain weight per ear, it was obtained from manual harvesting ears of 120 meters strands. In parallel, 5 ears of each repetition of the four classes of infestation for each variety whose flag leaf is free of any attack were harvested and placed in separate bags. The harvested ears were steamed for 24 hours at $105^{\circ} \mathrm{C}$ in order to remove internal moisture of the grain, and then ground and cleaned. 120 grains infested ears are individually weighed to determine the weight of grain/ear and 5 healthy ears are weighed separately to determine the average weight of grain/ear.

Yield loss was investigated by comparing the weight of grains per ear healthy and attacked. From each elementary plot, three heads whose leaves are infested with beetles were collected and stored in bags. After a manual threshing the grain is weighed and the average weight of grains per ear of each variety was determined. Subsequently, the relationship between the degree of infestation and grain weight/spike was demonstrated by the calculation of the regression equation and the coefficient of determination to study the nature and intensity of linkage between the two parameters using Microsoft Excel.

\section{RESULTS AND DISCUSSIONS}

Abundance of cereal leaf beetles Oulema spp: The results of the ten outputs highlight the presence of two species of beetle (Oulema melanopus and Oulema hoffmannseggi) at the experimental site cultivated with six durum wheat varieties: Megress, Ofanto Badre, Boussellem Mohamed ben Bachir and Zairi.

The population dynamics of the cereal leaf beetle was studied through the counting of individuals in each stage. The results of the absolute abundance and relative abundance of different stages are obtained by averaging the four repetitions of the populations of cereal leaf beetles (O. melanopus and O. hoffmannseggi).

Larval Evolution: We note that there is a gradual increase in the number of larvae during the first outputs. The maximum was reached at the 3rd output with an average of 24.83 larvae. It has an average of 23.25 larvae for Megress, 37.5 larvae for Ofanto and 35.25 larvae for Badre. Zairi follows this first group with a maximum observed at the 4th output with an average of 29.50 larvae. And finally, we found Bousselam and Mohamed Ben Bachir varieties; the maximum larvae were reached at the 5th output with an average of 27.25 and 18 larvae respectively (Table 1). The number increase of larvae is mainly explained by the release of larvae after hatching from eggs laid previously by the cereal leaf beetle females. Then a gradual decrease of larvae in all varieties until complete disappearance was observed. This decrease is explained by the entry into larvae pupate, in soil depth for $O$. melanopus and on upper parts of wheat for $O$. hoffmannseggi.

Evolution of populations of cocoons: The number of cocoons was gradually increased during the first outputs for all varieties after pupation beetle larvae. Maximum cocoons were observed at the 7 th output with an average of 20.87 cocoons (Table 1). Subsequently, the number of cocoons begins to decrease due to the mutation of cocoons as adults.

Concerning the varietal level, the maximum cocoons was reached at the 7th output, with an average of 33.5 cocoons for Badre variety, variety Ofanto (30.25 cocoons), Boussellem variety (24.75 cocoons), variety Zairi (17.75 cocoons), variety Megress (12 
cocoons), to 9 cocoons for Mohamed Ben Bachir variety.

Evolution of the population of adults: We have noticed a gradual decrease in the number of adults in the early outputs. The decrease in the number of adults is the first output progressive until the total disappearance at the 4th output for Megress, Badre, Boussellem Mohamed bin Bashir and Zairi varieties and at 5th exit for the Ofanto variety. The decrease in adult populations is explained by their disappearance after mating and spawning, the return to growth is due to the mutation of cocoons as adults. After, there is a gradual increase until it reaches the maximum in the 9th output with an average of 5.2 adults (Table 1).

Table 1: Temporal variation of absolute abundance and relative abundance for durum wheat

\begin{tabular}{|c|c|c|c|c|c|c|c|}
\hline \multirow{2}{*}{$\begin{array}{c}\mathbf{N}^{\circ} \\
\text { Outputs }\end{array}$} & \multirow{2}{*}{ Outputs dates } & \multicolumn{3}{|c|}{ Absolute abundance } & \multicolumn{3}{c|}{ Relative abundance } \\
\cline { 3 - 8 } & & Adults & Larvae & Cocoons & Adults & Larvae & Cocoons \\
\hline $\mathbf{1}$ & $\mathbf{1 4 / 0 4 / 2 0 1 1}$ & 1.70 & 2.58 & 0 & 0.129 & 0.024 & 0 \\
$\mathbf{2}$ & $\mathbf{2 0 / 0 4 / 2 0 1 1}$ & 1.33 & 8.70 & 0 & 0.101 & 0.079 & 0 \\
$\mathbf{3}$ & $\mathbf{2 7 / 0 4 / 2 0 1 1}$ & 0.66 & 24.83 & 2.45 & 0.050 & 0.232 & 0.026 \\
$\mathbf{4}$ & $\mathbf{0 5 / 0 5 / 2 0 1 1}$ & 0.04 & 22.83 & 8.75 & 0 & 0.213 & 0.095 \\
$\mathbf{5}$ & $\mathbf{1 1 / 0 5 / 2 0 1 1}$ & 0.08 & 22.20 & 12.37 & 0 & 0.207 & 0.135 \\
$\mathbf{6}$ & $\mathbf{1 9 / 0 5 / 2 0 1 1}$ & 0.04 & 18.45 & 17.54 & 0 & 0.172 & 0.192 \\
$\mathbf{7}$ & $\mathbf{2 5 / 0 5 / 2 0 1 1}$ & 0.45 & 5.41 & 20.87 & 0.034 & 0.050 & 0.228 \\
$\mathbf{8}$ & $\mathbf{0 1 / 0 6 / 2 0 1 1}$ & 0.66 & 1.91 & 14.87 & 0.050 & 0.017 & 0.162 \\
$\mathbf{9}$ & $\mathbf{0 8 / 0 6 / 2 0 1 1}$ & 5.20 & 0.08 & 10.87 & 0.395 & 0 & 0.119 \\
$\mathbf{1 0}$ & $\mathbf{2 0 / 0 6 / 2 0 1 1}$ & 3.00 & 0.00 & 3.58 & 0.227 & 0 & 0.039 \\
\hline
\end{tabular}

The reappearance of adults began during the 6th output for the variety Zairi, 7th output for Megress, Ofanto, Badre, and Boussellem varieties and at the 8th output for the Mohamed Ben Bachir variety. Once reappeared, the number of adult gradually increased to reach the maximum at the 9th output for all varieties, with averages of 3.25 adults for the Megress variety, 3.75 adults for Ofanto variety, 8 adults for Badre variety, 5.5 adults Boussellem variety, 4.25 adult Mohamed Ben Bachir variety and 6.5 adults for the Zairi variety. This increase is explained by the mutation cocoons as adults. At the 10 th output, there was a decrease in the number of adult beetles following the return of the winter holiday represented by various grasses and weeds in the vicinity of grain.

Relative frequency of beetles at the durum wheat varieties: The relative frequency of larvae, cocoons and adults, the percentage of these stages encountered during a trip by the total number of larvae, cocoons and adults counted in ten outputs. Thus, it appears that the period during which the larvae are most abundant is the 3rd output with a percentage of $24.83 \%$. While the period during which the cocoons are most abundant is the seventh release with a percentage of $22.80 \%$. And finally, the maximum adult is noted during the 9th output with $39.50 \%$ (Table 1).
Assessment of damage caused by cereal leaf beetles: The estimated damage caused by the beetles was studied by determining the rate of infestation of the plots obtained by counting the number of infested plants $/ \mathrm{m}^{2}$ of each variety on each repetition. The correlation between the rate of infestation of the flag leaf and grain weight per ear was demonstrated by the calculation of the regression equation and the coefficient of determination with a view to determine the nature and intensity of the link between two parameters. Based on the average grain weight per ear and average percentages of infestation of durum wheat varieties studied, we found that the coefficient of determination varies from lower $\mathrm{R}^{2}=0772$ for the Mohamed Ben Bachir variety at higher $\mathrm{R}^{2}=0930$ in the Zairi variety. That is to say, that $77 \%$ and $93 \%$ of the variability in grain weight/spike is explained by the variability in the degree of leaf flags infestation.

Weight loss per ear on infested flags leaves vary gradually according to the rate of infestation ranging from less than $10 \%$ to over $40 \%$ (Table 2). Thus, if the infestation is less than $10 \%$, the Boussellam variety proved most attacked by beetles and therefore weight loss per ear was equal to $3.48 \%$, while the most infested was Megress variety and loss of weight per spike was highest with a rate of $23.15 \%$. Boussellam proved still less infested Variety 
with other infestation rates, $10 \%-20 \%, 20 \%-40 \%$ and over $40 \%$ of infestation. In contrast, in a range of infestation of $10 \%$ to $20 \%$, the local variety Mohamed Ben Bachir, proved the most infested with more weight loss per spike. For the rest of infestation flags leave ranges, $20 \%-40 \%$ and $40 \%$, it is still the Megress variety which gave weight losses highest.

Table 2: Loss of weight per spike in the rate of infestation of the flag leaf

\begin{tabular}{|c|c|c|c|c|c|c|}
\hline Infestation range (\%) & Megress & Ofanto & Badre & Boussellam & MBB & Zairi \\
\hline $\mathbf{1 0 \%}$ & 23,15 & 3,7 & 4,39 & 3,48 & 12,12 & 10,31 \\
\hline $\mathbf{1 0 - 2 0} \%$ & 23,15 & 12,7 & 27,32 & 1,49 & 31,82 & 12,11 \\
\hline $\mathbf{2 0 - 4 0 \%}$ & 50 & 40,21 & 20,49 & 16,42 & 17,17 & 21,97 \\
\hline$\geq \mathbf{4 0} \%$ & 51,39 & 85,71 & 48,78 & 29,35 & 50,51 & 31,39 \\
\hline
\end{tabular}

Our results are consistent with those obtained by Dimitrijevic et al. (2001) found that larval density of cereal leaf beetle has an influence on the fall of the components yields and ultimately performance. The correlation between yield components and the number of larvae on the flag leaf is negative. The increase in larval density on the flag leaf is correlated with the decrease in component values yields of wheat and barley and thus with falling yields. If the flag leaf is damaged at $90 \%$ yield losses will be around $23 \%$ (Gallun et al., 1967).

\section{CONCLUSION}

The study of the population dynamics of cereal leaf beetles indicates the existence of two species of cereal leaf beetle at the station of the ITGC (agro-ecological zone), in this case Oulema melanopus and Oulema hoffmannseggi. Concerning the abundance of two species of beetles, we noticed the presence of a greater number of adults over Oulema hoffmannseggi than Oulema melanopus on all varieties. The same applies to the number of different stages of beetles vary according phenological stages of cereals and conditions.

The study showed a difference in the degree of attack of different varieties. The infection rate indicates that Badre is the most attacked variety followed by Zairi and Ofanto. This may be related to varietal characteristics including color, leaf width and early varieties.

The study showed that the infection rate of the flag leaf affects negatively grain weight per spike and therefore the total yield on all varieties studied, that is to say, when the percentage of infestation of the flag leaf increased grain weight per ear decreases.

\section{REFERENCES}

Bounechada M. (1990). Contribution à l'étude écologique des chrysomélidés (Coléoptère) de la région de Sétif. Magister thesis, Institute of Biology, University of Setif, Algeria. $172 p$.

Chambon, J.P., Van Laere, C., Genestier, G., Pineau, C., Coquempot C (1983). Étude des populations d'Oulema melanopus L. et Oulema lichenis Weiss. Coleoptères
Chrysomelidae) sur blé dans la région parisienne. Agronomie Vol. 3 No. 7: 685 p.

Gallun, L.R., Everly, T.R., Yamazaki, T.W (1967). Yield and milling quality of monon wheat damaged by feeding of cereal leaf beetle, J. Econ. Entomol. 60(2): 356-359.

Gillet, F (2000). La Phytosociologie synusiale intégrée. Guide méthodologique. Université de Neuchâtel, Institut de Botanique. Doc. Labo. Ecol. Vég. 1: 68p.

Kolarov, J (1988). Resistance of different wheats to the cereal leaf beetle Oulema melanopus L. (Coleoptera, Chrysomelidae), Cereal Res. Commun. 16(1-2): 19-23.

Maican, S., Serafim, R (2009). Data about Cerambycidae and Chrysomelidae (Coleoptera: Chrysomeloidea) collected from Mediterranean expeditions. Travaux du Muséum National d'Histoire Naturelle «Grigore Antipa». Vol. LII pp. 415-428

Olfert, O., Weiss, R.M., Woods, S., Philip, H., Dosdall, L (2004). Potential distribution and relative abundance of an invasive cereal crop pest, Oulema melanopus L. (Coleoptera: Chrysomelidae). Canada, Can. Entomol. 36: 277-287.

Royce, L.A., Simko, B (2000). Cereal Leaf Beetle: Identification, control, and California quarantine Act. EM 8762, Extension Service, Oregon State University, Oregon.

Ulrich W., Czarnecki A., Kruszyński, T (2004). Occurrence of pest species of the Genus Oulema (Coleoptera : Chrysomelidae) in cereal fields in north Poland, EJPAU 7(1), Poland.

Vitvitzky, A.M., Koval, M.N (1984). Opushenie listev pshenitzi i povrezhdenie pyavitzei, Zashita rasteny, Moskva. 10: 2223.

Webster, A.J (1977). The cereal leaf beetle in North America: Breeding for resistance in small grains, Ann. New York Acad. Sci. 287: 230-237.

Webster, A. J., Smith, H.D (1979). Yield losses and host selection of cereal leaf beetles in resistant and susceptible spring barley, Crop Sci. 19: 901-904.

Webster, A.J., Smith, H.D., Lee, C (1972). Reduction in yield of spring wheat caused by cereal leaf beetles. J. Econ. Entomol. 65(3): 832-835. 